\title{
A STUDY OF COMPARING CONCEPTUAL AND PERFORMANCE OF K- MEANS AND FUZZY C MEANS ALGORITHMS (CLUSTERING METHOD OF DATA MINING) OF CONSUMER SEGMENTATION
}

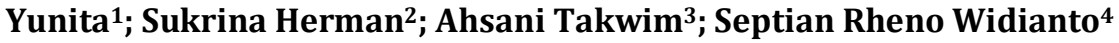 \\ Magister of Information System \\ STMIK LIKMI, Bandung, Indonesia \\ www.stmiklikmi.ac.id \\ yunita.nambela@gmail.com ${ }^{1 *}$, sukrinahermanheral01@gmail.com², \\ ahsanitakwim10@gmail.com ${ }^{3}$, septian.rheno@likmi.ac.id ${ }^{4}$ \\ ${ }^{*}$ Corresponding Author
}

\begin{abstract}
Consumers an important asset in a company that should be maintained properly especially potential customers. Tight competition requires companies to focus on the needs of the customer wants. Consumer segmentation is one of the processes carried out in the marketing strategy. To support the grouping process results consumers or consumer segmentation data mining is the support of a very important role. Based on mapping studies on data mining in support of consumer segmentation obtained two algorithms are often used for consumer segmentation include a K-Means Clustering and Fuzzy C-Means clustering. The attributes used for mining in customer segmentation processes are customer data, products, demographics, consumer behavior, transactions, RFMDC, RFM (Recency, Frequency Monetary) and LTV (Life Time Value). And it is important to combine the clustering algorithm to algorithm Classification, Association, and CPV to get the potential value of each cluster.
\end{abstract}

Keywords: Data Mining, Consumer Segmentation, Algorithm, Clustering.

\begin{abstract}
Abstrak
Konsumen merupakan asset penting dalam perusahaan yang harus dijaga dengan baik terutama pelanggan potensial. Persaingan usaha yang ketat mengharuskan perusahaan untuk berfokus kepada kebutuhan yang diinginkan oleh pelanggan. Segmentasi konsumen merupakan salah satu proses yang dilakukan dalam strategi pemasaran. Untuk mendukung hasil yang proses pengelompokan konsumen atau segmentasi konsumen ini maka dukungan data mining sangat berperan penting. Berdasarkan pemetaan penelitian mengenai dukungan data mining pada segmentasi konsumen didapat ada dua algoritma yang sering digunakan untuk segmentasi konsumen antara lain K-Means Clustering dan Fuzzy C-Means clustering. Adapun atribut-atribut yang digunakan untuk proses mining pada segmentasi konsumen adalah data konsumen, produk, demografi, perilaku konsumen, transaksi, RFMDC, RFM (Rerency, Frequency Monetery), dan LTV (Life Time Value). Dan penting untuk menggabungkan algoritma clustering dengan algoritma Classification, Association, dan CPV untuk mendapatkan nilai potensial dari tiap cluster.
\end{abstract}

Kata kunci: Data Mining, Segmentasi Konsumen, Algoritma, Pengelompokan

\section{INTRODUCTION}

Consumers are an important asset in a company that should be maintained properly especially potential customers. Tight competition requires companies to focus on the needs of the customer wants. With the large number of customers in a company need a strategy to define his company's potential customers by way of grouping customers. Grouping customers based on Their respective characteristics will affect a company's marketing management. Therefor to classify customers based on their respective characters needed methods, one of which Data Mining. Data mining is one of the sciences in the field of informatics study of data mining and text documents is one science that is mined. Clustering is a technique of one of the functionalities of data mining, clustering algorithm is an algorithm of grouping a number of data into groups - a group of specific data. 
Data mining is a theory that studies how to utilize historical data to find a pattern that is used to assist in decision making. The results of the mining process are patterns or pattern. These patterns are analyzed to find a new knowledge that is useful for managers in taking a decision. Support the decision of the mining process is normally used to help solve strategic problems for ordinary results found in the form of a prediction for the future. Business at the present time is very tight. Competition is everywhere. Especially with the market open so a company must conduct a process to improve its competitive advantage. Some of the ways that we engaged one is to build a system called Business Intelligence (BI). Business Intelligence (BI) is an integrated system which is coordinated by the Company. BI is built to support decision-making in all areas of the company including the top manager. BI combines the data storage and management knowledge to analyze it. The technique is done in between other BI ETL (Extract Transformation Loading), data warehouse, data mining and data visualization such as OLAP (Online Analytical Processing). This paper focuses on the area of data mining techniques in particular marketing strategy consumer segmentation. (Ranjan, 2007)

Clustering is a technique of one of the functionalities of data mining, clustering algorithm is an algorithm of grouping a number of data into groups - specific data group (cluster). There are many algorithms used in clustering, including the algorithm K-Means and Fuzzy C-Means (FCM). FCM is the algorithm clustering where one object can be members cluster and restrictions cluster FCM is sketchy. The basic concept of the FCM first is to determine the center of cluster. And each data point has a degree of membership for each cluster. The degree of membership in FCM algorithm is between 0 and 1. (Bora \& Gupta, 2014) Algorithm $\mathrm{K}$-Means is one algorithm clustering which is used to partition the data into some cluster, where the data has a high degree of similarity are grouped in one cluster whereas data that have different characteristics are grouped into cluster different (Elhabbash, 2010)

\section{MATERIALS AND METHODS}

On this research conducted a comparison between the clustering of the K-means and fuzzy clink C-means towards consumer segmentation. By comparing some previous research on the concept and performance of both methods of the clustering algorithm. Then after the comparison of the authors determine which method is better in the consumer segmentation process and whether there is a need to be done in improving the performance of the clustering method, or by combining both the algorithm Other data mining methods to get the best consumer segmentation. The following will describe the concept as well as the completion size of each algorithm in the clustering method.

The algorithm used in clustering are as follows.

\section{A. K-Means}

In the method of clustering the main concept is emphasized is the central search cluster iteratively, where the center determined based on the minimum distance of each data at the center cluster. Measures completion algorithm K-Means can be described as follows:

1. Identification data will cluster and also specify the number of cluster Data, Xij (i $=1,2$,

$n ; j=1,2, m$ ) where $n$ is the number of data to be cluster and $m$ is the number of data variables.

2. At the beginning of each iteration center cluster determined

Random (Random), $\mathrm{C}_{\mathrm{kj}}(\mathrm{k}=1 \mathrm{k} ; \mathrm{j}=1 \mathrm{~m})$.

3. Determine the distance of each data against center cluster by using Euclidean formula following:

$d_{i k}=\sqrt{\sum_{j=1}^{m}\left(X_{i j}-C_{k j}\right)^{2}}$

4. Group data based on the minimum distance of data toward the center cluster.

5. Check the condition if no data is still moving in the other group, if he did iteration next to the counting center cluster based on the average value of the data which are members of cluster which formed the previous iteration results using the formula:

$C_{k j}=\frac{\sum_{i=1}^{p} x_{i j}}{p}$

Where $\mathrm{X}_{\mathrm{ij}}$ is cluster to-k and number of cluster.

6. If no more data is moved on cluster the other, then the iteration process stops. In algorithm K-Means the data are regrouped on a cluster if the data has a minimum distance to the center cluster which can be calculated using the formula (2).

\section{B. Fuzzy C-Means}

Fuzzy C-Means is one of the methods fuzzy clustering who first developed by (Dewangan \& 
Ambhaikar, 2013) and later amended by (Dulyakarn \& Rangsanseri, 2001) as a method often used in pattern recognition (pattern recognition). FCM clustering in the data was based on the degree of membership value between 0 and 1.

In the FCM algorithm the first step is to determine the center of the cluster that will mark the average location for each cluster. In the initial condition, the cluster center is still inaccurate. Each data has a degree of membership for each cluster. By improving the cluster center and the membership value of each data repeatedly, it can be seen that the cluster center will go to the right location.

This loop is based on the minimization of the objective function that describes the distance from the data supplied to centers cluster which is weighted by the degree of membership of the data points. The output of the FCM is not a fuzzy inference system, but it is a center row cluster and some degree of membership for each data point. Steps to resolve the algorithm FCM algorithm in the first step Fuzzy C-Means can be described as follows:

1. Identification data will cluster in the form of a matrix size nxm (Xij = sample data to $\mathrm{i}(\mathrm{i}=1,2$, $\ldots \mathrm{n})$ and attribute $\mathrm{j}(\mathrm{j}=1,2, \ldots \mathrm{m})$.

2. Determine the number cluster (c), rank (w), maximum iteration (maxiter) error the smallest expected $(\bullet)$, the initial objective function ( $\mathrm{P} 0=0$ and the initial iteration $(\mathrm{t}=1)$.

3. Generating numbers random $\mu \mathrm{ik}(\mathrm{i}=1,2, . . \mathrm{n} ; \mathrm{k}$ $=1,2, . .$, c) as elements of the initial partition matrix $\mu$. Count the number of each column with the formula:

$$
Q_{j}=\sum_{k=1}^{c} \mu_{i k}
$$

Calculate the value of the matrix element partitioning member of the set $U$ by the formula:

$$
\mu_{i k}=\frac{\mu_{i k}}{Q i}
$$

4. Calculating the value of the center cluster all $\mathrm{k}$ $\left(\mathrm{V}_{\mathrm{kj}}\right.$ with $\left.\mathrm{k}=1,2, . ., \mathrm{c} ; \mathrm{j}=1,2, \ldots, \mathrm{m}\right)$

5. Calculate the objective function at the iteration to-t (Pt):

$$
\begin{aligned}
& P_{t}= \\
& \sum_{i=1}^{n} \sum_{k=1}^{c}\left(\left[\sum_{j=1}^{m}\left(X_{i j}^{-(2.6)}-V_{k j}\right)^{2}\right]\left(\mu_{i k}\right)^{w}\right) .
\end{aligned}
$$

6. Counting of change the partition matrix $\mu$.: $\mu_{i k}=\frac{\left[\sum_{j=1}^{m}\left(x_{i j}-V_{k j}\right)^{2}\right]^{\frac{-1}{w-1}}}{\sum_{k=1}^{c}\left[\sum_{j=1}^{m}\left(x_{i j}-V_{k j}\right)^{2}\right]^{-\frac{1}{w-1}}}$

7. Check the condition of stopping:

a. If (Pt - Pt-1) <• or ( $<<$ Max Iter) then the iteration stops.

b. If not: $t=t+1$, repeat steps 4 to 7 .

In the algorithm Fuzzy C-Means the data is grouped in a cluster, if the data has a maximum distance value partition matrix $U(\mu \mathrm{ik})$ towards the center cluster.

\section{RESULT AND DISCUSSION}

Several previous studies on the utilization of the K-Means algorithm and Fuzzy C-Means on consumer segmentation process, where the results of the study stated that the process of customer segmentation using KMeans algorithm and Fuzzy C-Mean The successful and unsuccessful. Following a discussion of some previous research.

\section{A. Utilization of The Algorithm K-Means Clustering on Customer Segmentation}

In (Amborowati \& Winarko, 2014) Most consumer segmentation process uses an algorithm $\mathrm{K}$ Means Clustering, and the results declared that successful and effective segmentation. K-Means Clustering Algorithm has several advantage, among others, provide a good solution to the problem of clustering for data objects that have a numeric attribute, relative scalable and efficient in processing a large data set, the algorithm is not sensitive to input the data, including fast algorithms in modeling and easy to understand. Perform customer segmentation algorithm using $\mathrm{K}$ Means Clustering with RFMDC attributes. RFMDC is the development of RFM models (recency, frequency, monetary) used to do segmentation consumer Where development is diversity and continuousness.

In (Shashidhar \& Varadarajan, 2011) to segment consumers by uses two data mining algorithms, the first to do is to segment with Neural network to have equal type at the time of sample data used in the different categories. Results from the first step is used as input in the KMeans algorithm Clustering.

The use of K-Means more by (Khajvand \& Tarokh, 2011), where for customer segmentation using K Means Clustering and Decision Tree for the classification. The first step performed to determine RFM parameters that by making scale of 
based transactions, demographics, and products. The second step of the process using $\mathrm{K}$ means clustering segmentation based on the results of FRM. As with the (Amborowati \& Winarko, 2014) in his paper did consumer segmentation with using the two-step. The first step uses K-Means Clustering to produce cluster based on the demographic and step both using Neural Network to calculate the potential value of each cluster.

While Li, 2010, do customer segmentation KMeans Clustering for get four consumer groups, and predict using C5.0, Neural Network, Chi squared automation interaction detector (CHAID). The result is a new consumer and potential value.

\section{B. Utilization of Fuzzy C-Means Algorithm Clustering On Consumer Segmentation}

Research by Megawati, Mukid, and Rahmawati about the use fuzzy c-means algorithm for market segmentation. Here, researchers used algorithms fuzzy c means for classifying consumers into two clusters based on 10 variables psikografik. Data were obtained through questionnaires Pasaraya RITA Cilacap. Result of research on this study show that consumen segmentation is divided into 2 cluster. respondents in cluster 1 pay attention to the level of low prices, the completeness of goods goods, large discounts, service when shopping satisfying, convenient location, spacious parking, the convenience when shopping, adequate public facilities, facilities complete payment, and the cleanliness of the room compared to respondents in cluster 2. With this research the right target market can be applied to a self-service in accordance with case studies taken by the researcher.

Research by Dewi Astria and Suprayogi about application of fuzzy c-means algorithm Clustering in CV Mataram Jaya Bawen. This study using Fuzzy C-Means (FCM) in data processing transactions by customers. Calculation algorithm consists of initialization data such as membership data, calculating a centroid, calculates the distance to the centroid of data, calculate the value of membership, and calculate the value of the objective function. Objective function value affects the iteration is done, because if the change has not reached the objective function value the smallest positive value iteration will continue to do. Once the objective function value reaches the small positive value, then cluster data can be determined. End formed clusters show that the number of consumers 28 golden, 14 silver, and bronze 33 . Here are the results of the graphical display that shows the number of customers who are in a cluster, and make CV Mataram Jaya Bawen easy to monitor customers.

\section{Graph of Calculation Result}

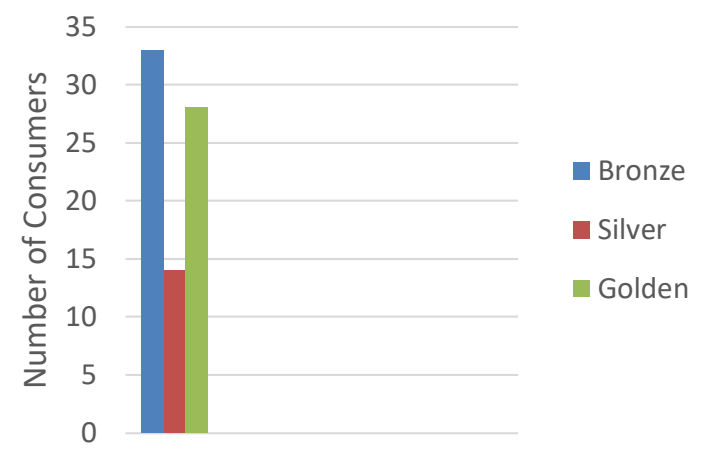

Source: (DewiAstria, 2017)

Figure 1. Cluster Number of customers CV Mataram Jaya

To determine the validity of cluster in formation cluster customers on the system, Dewi Astria and Suprayogi calculating partition coefficients or partition coefficient (PC) as the evaluation of the value of membership data at each cluster. Values greater (closer to 1) means that the quality cluster obtained the better. results to calculate the accuracy of the PCI Index cluster is 0.596277. In the study, Fuzzy C-Means algorithm works well in doing clustering customers. The algorithm classifies customers into three clusters (golden, silver and bronze) with the accuracy of the cluster is 0.596277 , which means pretty good degree of accuracy.

\section{The attributes used for segmentation consumer}

At the time of clustering will be used attributes for mining process. The attributes that are often used to segment customers include consumer data, demographic factors, type of product, consumer behavior, consumer transactions to the product, RFM, (RFMDC (recency, frequency, monetary, diversity and continuousness) and LTV (life time value), value information, and behavior information.

Table 1. Attributes are used to perform customer segmentation

\begin{tabular}{|c|c|c|c|}
\hline No & Author Name & Year & Atribut \\
\hline 1 & $\begin{array}{l}\text { Lin, Jian Bang., } \\
\text { Liang Tehsin, } \\
\text { Lee, Yong-goo, } \\
2012\end{array}$ & 2012 & $\begin{array}{l}\text { Demografi, } \\
\text { Product }\end{array}$ \\
\hline 2 & $\begin{array}{l}\text { Ye, Luo., Qiu-ru, } \\
\text { Cai., Etl, } 2012\end{array}$ & 2012 & $\begin{array}{l}\text { Customer: } \\
\text { identifikasi } \\
\text { konsumen, } \\
\text { metode kontak, }\end{array}$ \\
\hline
\end{tabular}




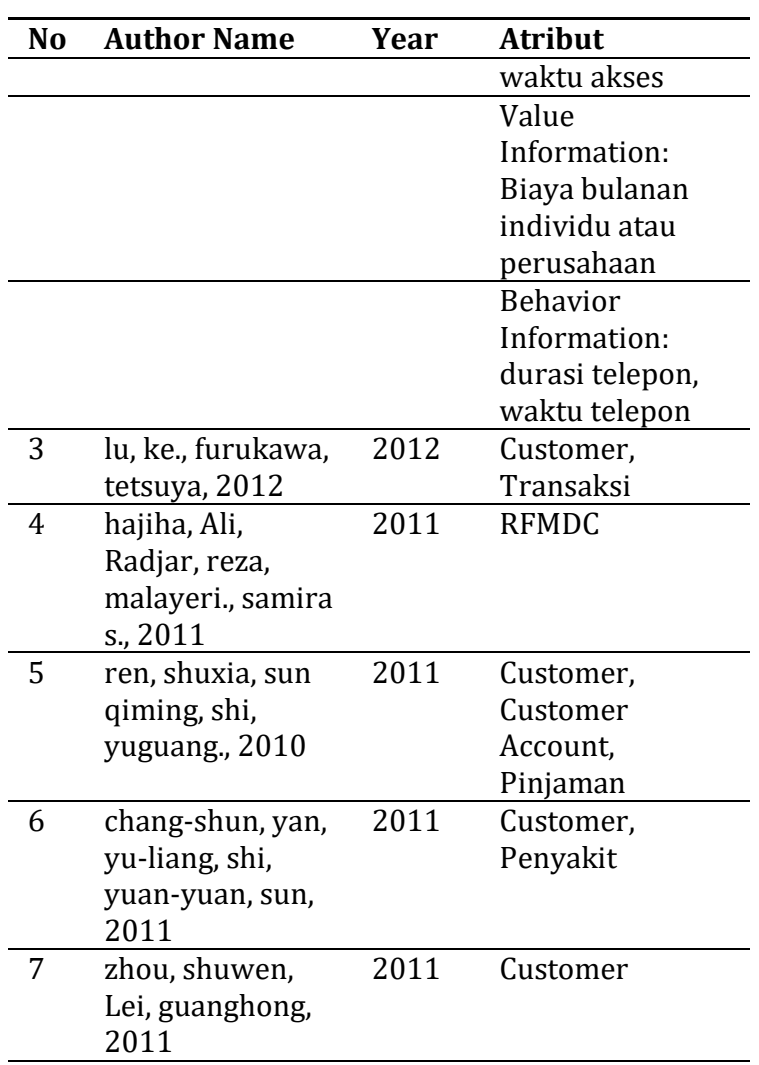

Data CRM: umur, jenis kelamin, pendidikan, pekerjaan, status pernikahan, pendapatan

\begin{tabular}{|c|c|c|c|}
\hline 8 & $\begin{array}{l}\text { bonsnjak, z., } \\
\text { grljevic, o., } 2011\end{array}$ & 2011 & $\begin{array}{l}\text { Customer, } \\
\text { Pinjaman }\end{array}$ \\
\hline 9 & $\begin{array}{l}\text { yao, Zhiyuan, } \\
\text { eklund, thomas., } \\
\text { back, barbro, } \\
2010\end{array}$ & 2010 & $\begin{array}{l}\text { Demografi, } \\
\text { Perilaku } \\
\text { konsumen }\end{array}$ \\
\hline 10 & $\begin{array}{l}\text { namvar, } \\
\text { morteza, } \\
\text { glolamian, M.R, } \\
2010\end{array}$ & 2010 & $\begin{array}{l}\text { RFM (Ferency, } \\
\text { frequebcym } \\
\text { monetery) } \\
\text { Demografi, LTV } \\
\text { (life time value) }\end{array}$ \\
\hline 11 & $\begin{array}{l}\text { yu, gu, jiahui, li, } \\
2010\end{array}$ & 2010 & customer value \\
\hline 12 & Bi, jianxin, 2010 & 2010 & $\begin{array}{l}\text { customer value, } \\
\text { product, pangsa } \\
\text { pasar }\end{array}$ \\
\hline 13 & $\begin{array}{l}\text { wang, wei, fan, } \\
\text { shidong, } 2010\end{array}$ & 2010 & $\begin{array}{l}\text { customer, } \\
\text { transaksi }\end{array}$ \\
\hline 14 & $\begin{array}{l}\text { Yihua, Zhang, } \\
2010\end{array}$ & 2010 & $\begin{array}{l}\text { customer, } \\
\text { product, } \\
\text { transaksi } \\
\end{array}$ \\
\hline 15 & $\begin{array}{l}\text { Li, We, Wu, } \\
\text { Xuemei, } 2010\end{array}$ & 2010 & $\begin{array}{l}\text { Application } \\
\text { Source, Number } \\
\text { Credit Card }\end{array}$ \\
\hline & & & $\begin{array}{l}\text { frekuensi } \\
\text { penggunaan, } \\
\text { demografi } \\
\text { konsumen } \\
\end{array}$ \\
\hline
\end{tabular}

Source: (Amborowati \& Winarko, 2014)

\section{CONCLUSIONS AND SUGGESTION}

Consumer segmentation is fundamental to the marketing strategy. To support the process of grouping the results of the consumer or This consumer segmentation then support data mining is very important. Data mining algorithm that is most appropriate and often used for segmentation is a K-Means Clustering and Fuzzy C Means. Advised on the comparative performance of the two algorithms are the grouping to do the merge customer data clustering algorithm (K means Clustering and Fuzzy C-Means) with some data mining algorithms such as Classification, Association, and CPV matrix to obtain the potential value of each cluster. The attributes used to process mining on consumer segmentation is customer data, product, demographics, consumer behavior, transactions, RFMDC, RFM (Recency, Frequency Monetary) and LTV (Life Time Value).

\section{REFERENCES}

Amborowati, A., \& Winarko, E. (2014). Review Pemanfaatan Teknik Data Mining Dalam Segmentasi Konsumen. Prosiding Seminar Ilmiah Nasional Komputer Dan Sistem Intelijen (KOMMIT 2014), 8(Kommit), 66-73.

Bora, D. J., \& Gupta, D. A. K. (2014). A Comparative study Between Fuzzy Clustering Algorithm and Hard Clustering Algorithm. International Journal of Computer Trends and Technology, 10(2),

108-113.

https://doi.org/10.14445/22312803/ijcttv10p119

Dewangan, O., \& Ambhaikar, P. A. (2013). Extended Fuzzy C-Means Clustering Algorithm in Segmentation of Noisy Images. International Journal of Scientific Engineering and Research (IJSER), 1(1-3), 16-19.

DewiAstria, S. (2017). Penerapan Algoritma Fuzzy C-Means Untuk Clustering. Universitas Dian Nuswantoro Semarang, 6(Maret 2017), 169178.

Dulyakarn, P., \& Rangsanseri, Y. (2001). Fuzzy cmeans clustering using spatial information with application to remote sensing. 22nd Asian Conference on Remote Sensing, 2(November), 2-5.

Elhabbash, A. H. (2010). Enhancedk-means 
Clustering Algorithm. The Islamic University of Gaza. Retrieved from https://iugspace.iugaza.edu.ps/handle/20.5 $00.12358 / 18772$

Khajvand, M., \& Tarokh, M. J. (2011). Analyzing Customer Segmentation Based on Customer Value Components (Case Study: A Private Bank) (Technical note). Journal of Industrial Engineering, 79-93. Retrieved from https://www.sid.ir/en/journal/ViewPaper.a spx?id=351714

Ranjan, J. (2007). Applications of Data Mining Techniques in Pharmaceutical Industry. Journal of Theoretical \& Applied Information Technology, 3(4), 61-67.

Shashidhar, H., \& Varadarajan, S. (2011). Customer Segmentation of Bank based on Data Mining - Security Value based Heuristic Approach as a Replacement to K-means Segmentation. International Journal of Computer Applications, 19(8), 13-18. 